\title{
THE USE OF FOG AND SMOKE IN FROST DEFENCE
}

\author{
YRJÖ Pessi \\ Frost Research Station, Pelsonsuo.
}

Received November 22, 1955

According to the genesis of the frost phenomenon, a distinction is made between radiation frost, valley frost and advection frost. In the genesis of all of these the radiation of the earth's surface is a contributing factor. One of the ways of attempting to prevent the formation of frost is thus to reduce this outgoing radiation. In small areas this is best accomplished with the aid of various kinds of protective covers. In cultivated fields, on the other hand, a reduction of the rate of radiation is more difficult to achieve. One of the methods is to provide the cultivated area with an artificial smoke or fog screen in an attempt to imitate its natural shield, the cloud cover.

Experiments with smoke and fog generating methods have been made already at the end of the last century. Lemström (7) experimented with his frost torches, a kind of smoke cartridges containing peat, resin, coal, tar, sulphur and saltpetre. No accurate data are available on the protective effect of this method, but probably it has been inefficient. RINDELL and KARSTEN (10) carried out experiments with frost piles having in their interior dry twigs and other kinds of smoke-generating refuse, and on the outside a wet peat layer. According to their observations they achieved in a test before midnight September 12th, 1912, a temperature difference of $1.3^{\circ} \mathrm{C}$ between the fogged and non-fogged area. Their thermometers were placed in huts. The same authors also carried out tests with smoke alone, using various mixtures of peat and peat litter for the generation of smoke. According to them the results were not satisfactory, which they attributed to the fact that the smoke was not particularly abundant and that the particles were large.

Foss (2) has carried out tests in Norway with frost piles. He makes the observation that on the strength of the smoke screen generated by the piles the air temperature on the fogged area could remain $1.5^{\circ} \mathrm{C}$ higher than outside this area. HvoD $\left(4\right.$, p. 39) also reports the attainment of temperature differences of $1-1.5^{\circ} \mathrm{C}$ with the aid of frost piles. 
The experiments with chemical fogs were commenced in the 1920 's. A very great variety of different smoke and fog substances have indeed been tested in this sense $(2,4,5,8,12)$. A great number of the experiments have been of a technical character. However, also such tests are reported in which attention was paid to the temperature differences between the fog-treated and the untreated area. HvoD $(4$, p. $38-40)$ relates that he observed temperature differences amounting to $1-1.5^{\circ} \mathrm{C}$ when fog had been generated by means of phosphorus. In Sweden experiments have been made with a fog-generating method in which fog has been produced by allowing chlorosulphonic acid to drop upon quicklime (12). In these trials WinkLER mentions temperature differences of about $1^{\circ} \mathrm{C}$ between the fogged and non-fogged area.

The Frost Commission of Northern Finland has arranged experiments during the years 1946-1947 under the direction of LAINE according to the method of LAINE $(5,6)$. This frost defence method is based upon the formation of fog, which takes place, in the device Model la with the aid of sulphur trioxide $\left(\mathrm{SO}_{3}\right)$ and water vapour, in Model $1 \mathrm{~b}$ exclusively with sulphur trioxide (5, p. $123-130 ; 6$, p. $4-5)$. LAINE $(6$, p. $13-27)$ states that temperature differences of $3-4^{\circ} \mathrm{C}$ were achieved with water vapour - sulphur trioxide fog on several nights in tests carried out at Pikkarala. He reports a highest temperature difference of $7^{\circ} \mathrm{C}$, which was obtained at the Agricultural School in Ruukki on the night between September 2-3, 1947.

\section{Experiments and investigations of the Frost Research Station}

In the years 1951, 1952 and 1954 experiments and investigations relating to some fog-generating methods have been performed on the fields of Pelso penitentiary. Subjects of investigation were: fog generated by sulphur trioxide, water vapour fog, and fog produced by a combination of both.

In the summer of 1951 the effect of fog was studied by performing temperature measurements within the fogged area and outside the same with alcohol minimum thermometers (by R. Fuess) and thermographs, in order to observe any temperature difference which might be produced by the fog procedure. In order to establish the natural temperature differences between the compared ground points, temperature measurements were carried out on each day from the beginning of June, throughout the period of growth. All points of measurement grew spring cereals.

On the night between July $23-24$, a test was carried out on a cultivated area of about 300 ha. The site was of even formation and comprised only cultivated peat soil. Both types of LAINE frost-prevention devices were used, 20 of each kind. It was possible to generate a fog layer over the area, which was continuous later at night. Horizontal visibility was about $100 \mathrm{~m}$ and the fog layer had a thickness of $2-3 \mathrm{~m}$. The temperature within the fog area went down to $-2.2^{\circ} \mathrm{C}$. No differences in minimum temperature caused by the fog procedure were observed.

In 1952, in the night between August 15-16, a test was made on the same area and on the same scale. No water vapour-generating substances were used in the devices, nor did the formation of fog proceed as succesfully as the year before. Frost 
damage to the plants could not be prevented, the temperature falling to $-5.0^{\circ} \mathrm{C}$. Even now no differences in minimum temperature caused by the fog were noted.

In the investigations described above, both in those carried out abroad and those in our country, the effect of fog has been studied by means of temperature measurements within the fog area and outside the area under fog. This method of investigation appears to be inconvenient in practice, and so reliable results are difficult to obtain. In the first place the investigations are impeded by the fact that it is difficult to find a suitable point of comparison for the temperature measurements outside the fog area, the requirement being that the fog must not be carried to the chosen point of observation. Furthermore the reliability of the results depends upon whether multiples are used in the temperature measurements and whether the natural temperature differences between the points of measurement are known. The use of multiples is necessary because the temperature variations may amount to $0.6^{\circ} \mathrm{C}$ even in similar vegetation (Table 1). If again the natural temperature differences between the measuring points have not been studied previously, it will be difficult to ascertain what part the fog plays in the occurrence of differences in temperature. It is sufficient to point out that merely over a different cover of vegetation the thermometer may indicate a different temperature (Table 1), not to speak of the significance of orographic factors. As is seen from Table 1, the minimum temperatures of the days concerned in the table differ, for instance, between an oat field and a grass meadow by nearly $1^{\circ} \mathrm{C}$ on an average.

Table 1. Minimum temperature of the air, as measured at the upper limit of vegetation and at a height of $5 \mathrm{~cm}$ from the bare soil surface. Two multiples. The deviations from their mean have been stated after each value.

\begin{tabular}{|c|c|c|c|c|c|c|}
\hline & Night & & Oat field & Potato field & Bare field & Grass meadow \\
\hline $19-20$ & August & 1954 & $-1.4 \pm 0.2$ & $-1.7 \pm 0.1$ & $-2.2 \pm 0.2$ & $-2.3 \pm 0.3$ \\
\hline $20-21$ & $"$ & $"$ & $-2.2 \pm 0.2$ & $-2.6 \pm 0.2$ & $-3.4 \pm 0.1$ & $-3.0 \pm 0.1$ \\
\hline $\begin{array}{l}21-22 \\
\text { Average }\end{array}$ & $"$ & $"$ & $\begin{array}{l}-1.3 \pm 0.2 \\
-1.6\end{array}$ & $\begin{array}{l}-1.7 \pm 0.2 \\
-2.0\end{array}$ & $\begin{array}{l}-2.2 \pm 0.1 \\
-2.6\end{array}$ & $\begin{array}{l}-2.2 \pm 0.2 \\
-2.5\end{array}$ \\
\hline
\end{tabular}

A more reliable idea of the capacity of smoke or fog to reduce the effective outgoing radiation is actually obtained if recourse is taken to direct measurements, which reveal in what degree the effective outgoing radiation is lowered by these agents. According to Kessler and KaempFert (8) a reduction of the effective outgoing radiation by about $50 \%$ can be achieved with the aid of artificial fog. WinkLER (12) mentions measurements performed in Germany and in America, where the reduction of the effective outgoing radiation was even higher. However, he states further that the achieved temperature differences have not been in excess of $1-1.5^{\circ} \mathrm{C}$.

After a radiation balance meter (11) had become available at the Frost Research Station in the summer of 1954, this instrument was used during some nights to investigate in what degree water vapour fog and fog produced by sulphur trioxide, as well as that caused by these substances in combination, reduced the effective outgoing radiation. The radiation balance meter was checked against a MicHELsoN bimetal actinometer in May 1954. Since the instrument in question yields values 
which are $6 \%$ too small at night-time (11, p. 280), this correction was applied to the results. The method of the investigation was to measure the radiation balance continuously throughout the night and to generate fog over the cultivated area time after time. The sulphur trioxide fog and the fog from the combination of this agent and water vapour were generated with the aid of the devices of LAINE. The pure water vapour fog was produced by heating wet moss. Furthermore a study was made of the influence of natural fog upon the effective outgoing radiation.

The fog layers generated with the devices of LAINE had a thickness of about $2-3 \mathrm{~m}$, the horizontal visibility in the fog being about $30 \mathrm{~m}$. The water vapour fog had a thickness of $1-2 \mathrm{~m}$, with a visibility of about $150 \mathrm{~m}$. The natural fog was of $2-3 \mathrm{~m}$ thickness, visibility in the fog about $150 \mathrm{~m}$. The results of the measurement are presented in Fig. 1. For the sake of comparison also the effective outgoing radiation of various covers of vegetation has been shown in the figure, whereas the effect of the fog produced by sulphur trioxide and water in combination has been omitted. This was done because this fog gave completely similar results to the other kinds of artificial fogs.

Discussion of the results of investigation and criticism of the fog generating methods

Although no differences in the minimum temperatures attributable to the effect of the generation of fog occurred in the tests in 1951 and 1952, this does not necessarily imply that fog would not be able to produce temperature differences in some circumstances. The tests show, however, that in large open areas, of which type the investigation site was, no temperature differences can be brought about in practice. In cultivated areas confined by forests, which type was represented by the experimental site of LAINE at Pikkarala, this may be possible, particularly if fog is generated efficiently throughout the night. On the other hand it has to be noted that even if no differences in minimum temperatures would be achieved, this does not necessarily mean that the preventivew ork is totally wasted. Frost damage is not entirely dependent on the minimum temperature, but also on the time during which the temperature remains below the freezing point. Even the prevention of a fall in the temperature for a shorter time will thus reduce the damage.

Table 2. The effect of cloudiness upon effective outgoing radiation, according to Ångström in Uppsala. Cloud cover

$0 \quad 10 \mathrm{Cs}$ - 10 as. 10 low clouds

\begin{tabular}{|c|c|c|c|c|}
\hline tion, $\mathrm{gcal} / \mathrm{cm}^{2} \mathrm{~min}$ & 0.169 & 0.135 & 0.039 & 0.023 \\
\hline Reduction, $\% \quad \ldots \ldots \ldots$ & . & 20.1 & 76.9 & 86.4 \\
\hline
\end{tabular}

According to the investigations at the Frost Research Station the quality of the fog seems to be of no significance as regards the degree in which the effective outgoing radiation is reduced, although a quantitative comparison between the different types of fog is difficult to perform. Naturally, better results are achieved with thicker layers of fog, but this meets with practical difficulties. 


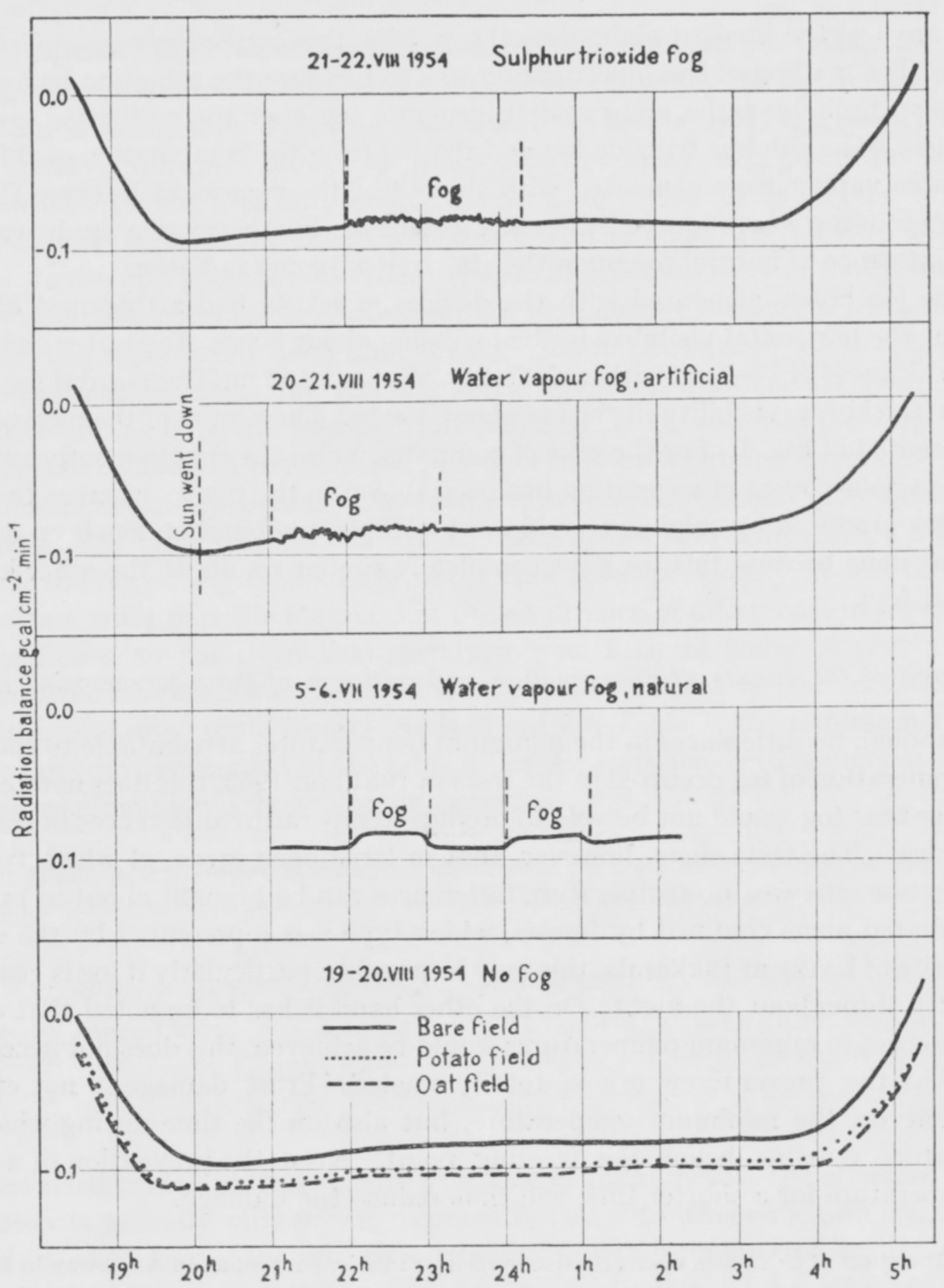

Fig. 1. The effect of fogs and vegetation upon effective outgoing radiation.

Deciding on the significance of the fog generating methods as a means of defence against frost, attention has to be paid to two points: the efficiency of the method as a means to reducing the effective outgoing radiation, and its suitability for practical use. All of the above-mentioned fogs, which were investigated at the Frost Research Station, reduced the effective outgoing radiation, and are thus theoretically suitable for frost defence work. However, there are situations in which quite generally such fogs, which aim at a reduction of the effective outgoing radiation, have not 


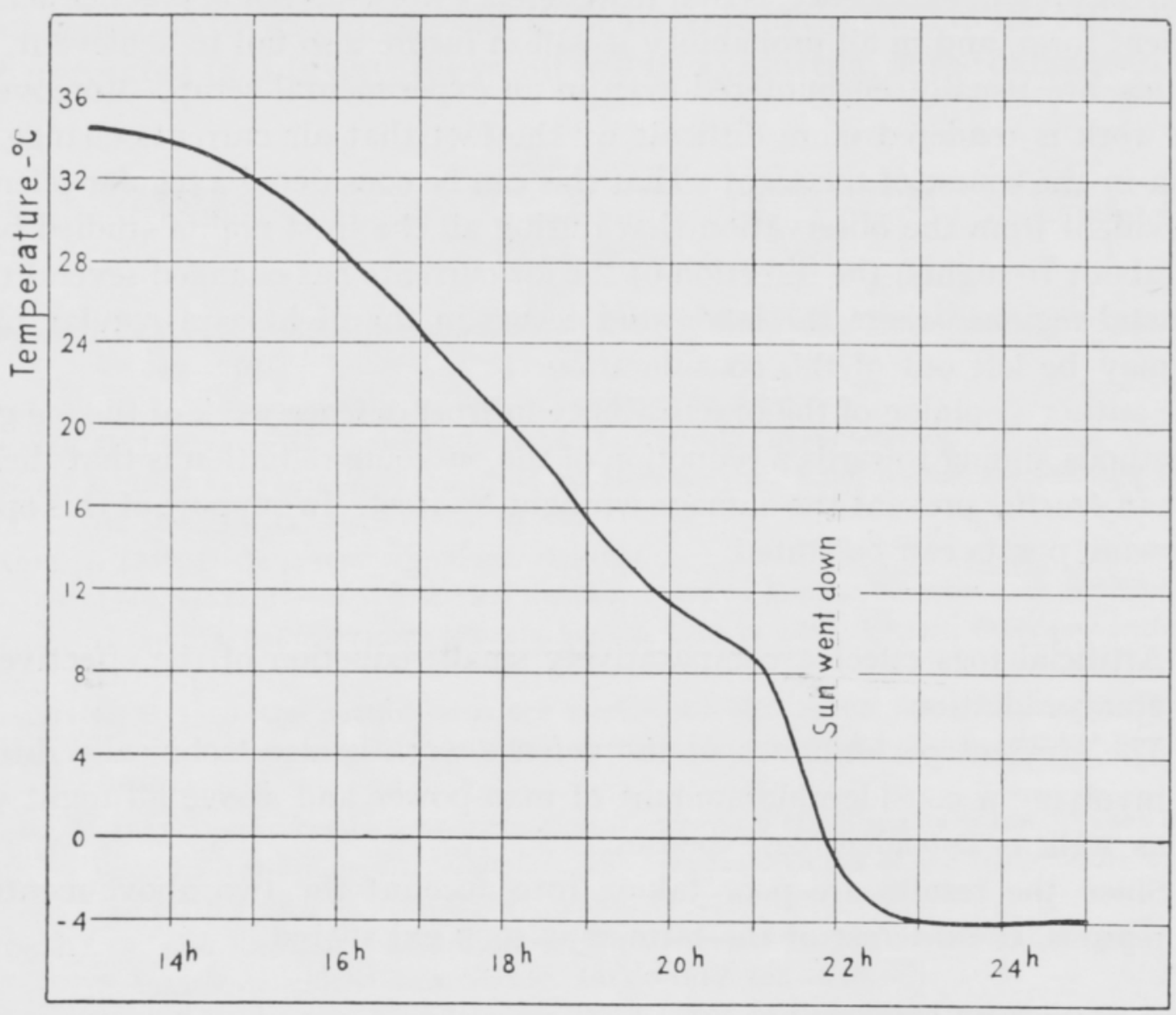

Fig. 2. Temperature of the air at the soil surface.

even a theoretical chance to diminish the damage wrought by frost. Such frost situations are those in which the vertical temperature gradient in the air layers close to the soil surface is very small or non-existent (9).

In order to estimate what chances there are for achieving positive practical results by the generation of fog, it is necessary to consider how the frost defence activity could be arranged so as to achieve the best possible result.

It is seen from Fig. 1 that on the night of August 20, 1954, the radiation balance was negative as early as over one hour before sunset, and that the effective outgoing radiation was at its maximum at the very moment of sunset. Similarly, the radiation balance continued to be negative for some time after sunrise. Fig. 2, again, shows how rapidly a fall in the temperature can take place at sunset or even earlier. On the frost night in question the temperature was $0^{\circ} \mathrm{C}$ already at sunset, at the top of the young crop even though the day-time temperature had risen above $34^{\circ} \mathrm{C}$. Thus the generation of fog should be started already before sunset, at the time when the radiation balance becomes negative. The generation of fog should also be continued without interruption after sunrise, until the radiation balance becomes positive again. This results in a relatively long period of the defence work. The author's opinion, 
based on his present experience, is that frost defence work has not in practice achieved an efficient form, and in all probability it will in future also fail to achieve it, since difficulties are usually encountered even in an experimental setup. Moreover the defence work is rendered more difficult by the fact that air currents change their direction in the course of the night. That this can be considered a regular phenomenon is evident from the observation that during all the frost nights studied by the author (about 70 nights) the direction of the air currents has changed several times. The coastal regions, where the land wind occurs in the night as a regular phenomenon may be left out of this consideration.

The author's opinion of the practicability in frost defence work of the fog generating methods aiming towards a reduction of the outgoing radiation is that their use does not in practice prevent the damage wrought by frost. In support of this opinion the following points can be stated:

1. Artificial fogs effect a comparatively small reduction of the effective outgoing radiation.

2. The efficient performance of the defence work is also technically difficult, involving a considerable amount of man-power and above all night work, as well as considerable expenses.

3. Since the results are poor taking into account the two above-mentioned reasons, the interest of the farmers is soon exhausted.

\section{On the possibilities of developing the fog generating methods}

In spite of the foregoing, possibilities may be found for the use of the fog generating methods in frost defence work. However, a development of the methods on the principles described above, i.e. with a view to a reduction in the effective outgoing radiation, is not to be recommended in view of the practical difficulties. On the contrary, the work of development should be directed along the same lines that are followed in the sprinkling of the superterrestrial parts of the plants, a measure which aims at the formation of a protecting ice sheath around the plant parts. As the water freezes heat is liberated, from which the plants and the surrounding air benefit. Moreover, the wetting of the soil improves its thermal conductivity. However, sprinkling has the drawback that it cannot be contemplated on extensive fields without special sprinkling equipment. On the other hand, fog is carried even over extensive cultivated areas, but it is too light to descend to the earth. The objective is thus to find an intermediate form between fog generation and sprinkling by producing a fog of such droplet size, or otherwise of such properties that it will descend after floating for a certain time. In this way the sprinkling of the superterrestrial plant parts would become possible even on large farming areas. Another new idea could then be combined to the action of this fog. It might be possible, by the use of some appropriate chemicals carried by the fog, or used in its generation, to achieve 
a lowering of the freezing point of the fluid in such cell interstices into which this salt can penetrate by way of osmosis. If the freezing of the fluid in the cell interstices can be prevented in this way, the result will be a reduction of the damage to the cell walls.

\section{REFERENCES}

(1) Angervo, J. M. 1947. Hallantorjunnasta varsinkin viimeaikaisten tutkimusten mukaan. Pellervo 48: $344-346$.

(2) Foss, H. 1929. Nattefrost, dens årsaker og bekjämpelse. Oslo.

(3) Geiger, R. 1942. Das Klima der bodennahen Luftschicht. Braunschweig.

(4) Hovd, A. 1933. Røyking mot nattfrost på Maeresmyra. Meld. norske myrselskaps fors. stasj. på Maeresmyra, 1931-1932: 36 - 46 .

(5) Laine, T. 1947. Halla ja sen torjuminen. Helsinki.

(6) —- 1948. Hallantorjunta kokeiden valossa. Selostus Pohjois-Suomen hallatoimikunnan suorittamista hallantorjuntakokeista kesällä 1946 ja 1947. Report: Frost-preventing experiments.

(7) Lemström, S. 1893. Om nattfrosterna och medlen att förekomma deras härjningar. Helsingfors.

(8) Kessler, O. \& Kaempfert, W. 1940. Die Frostschadenverhütung. Reichsamt für Wetterdienst, Wiss. Abh. 6, 2.

(9) PESsi, Y. 1955. Pystysuorasta lämpötilanjakaantumisesta maan pinnasta ylöspäin ja sen merkityksestä hallantorjunnassa. Summary: The vertical dividing of the temperature upwards of the earth's surface. Maatal. tiet. aikak. 27: 154-160.

(10) Rindell, A. und Karsten, H. 1913. Savun käyttämisestä suojelukeinona ballan tuhoja vastaan. S. maanv.-taloud. koelait. vuosik. 1911-1912: 103-116.

(11) Suomi, V. E. \& Franssila, M. \& Islitzer, N. F. 1954. An improved net-radiation instrument. J. Meteor. 11: 276-282.

(12) WinkleR, H. 1949. Konstgjord dimma som skydd mot nattfrost. Grundförbättring 3: 1-14.

SELOSTUS:

SUMUJEN JA SAVUJEN KÄYTTÖ HALLANTORJUNNASSA

YRJÖ PESSI

Hallakoeasema, Pelsonsuo.

Hallakoeasemalla suoritettiin hallantorjuntakokeita rikkitrioksidi-, vesihöyry- ja näiden molempien yhdessä muodostamalla sumulla. Lisäksi tutkittiin näiden ja luonnon sumun vaikutusta tehoisaan ulossäteilyyn.

Pelsonsuon laajoilla viljelyksillä ei sumutusmenetelmillä saatu muodostumaan lämpötilaeroja sumutetun ja sumuttamattoman alueen kesken. Kaikki keinotekoiset sumut vähensivät tehoisaa ulossäteilyä jokseenkin samalla tavoin, korkeintaan $10 \%$. Keinotekoisten sumujen ja luonnon sumun välinen ero ilmeni siinä, että keinotekoisten sumujen aikaansaama tehoisan ulossäteilyn vähennys vaihteli, mutta luonnon sumu aikaansai yhtämittaisen $10 \%$ vähennyksen. Edelleen tutkimuksissa todettiin, että kasvipeitteen vaikutus tehoisaan ulossäteilyyn oli jo suurempi kuin tutkimuksissa esiintyneiden sumujen.

Tutkimusten perusteella todettiin, että vaikka sumutusmenetelmät teoreettisessa mielessä ovat tutkimuksen arvoisia hallantorjuntakeinoja, useat seikat aiheuttavat kuitenkin sen, että kä y tä nnös s ä niillä ei ole merkitystä hallantorjunnassa. 